\title{
A INAPLICABILIDADE DA ADVERTÊNCIA ESCRITA NAS SANÇÕES DE TRÂNSITO
}

\author{
Daniel Angelo Passaia* \\ Luciana Turatt $^{* *}$
}

\begin{abstract}
RESUMO
O presente artigo tem como escopo o direito de trânsito brasileiro, área não esmiuçada com a profundeza que merece, notadamente quando se trata da jurisprudência e doutrina especializada. O estudo é relacionado diretamente às sanções previstas nas normatizações do direito de trânsito - Lei 9.503/97 - e, nesta conjectura, pontualmente atinente a substituição da multa pecuniária pela advertência por escrito, cuja estipulação histórica e social, distingue-se amplamente das atuais finalidades. O texto legal é do art. 267 da lei retro citada, conhecida como Código de Trânsito Brasileiro. A problemática, portanto, reside na inaplicabilidade da advertência por escrito, mesmo diante da previsão legal. Hipoteticamente verifica-se afronta à esfera jurídica do indivíduo que sofre aplicação de sanções de natureza leve ou média. $\mathrm{O}$ estudo tem por método o qualitativo e como técnicas utiliza-se da análise bibliográfica e documental. A consulta à jurisprudência demonstrou inexistirem resultados contemplando esta discussão em específico, enquanto a doutrina impõe algumas exigências que não se vislumbram na legislação, o que, fez incontroversa, ao menos neste tempo e espaço, a hipótese lançada inicialmente. $\mathrm{O}$ estudo atinge diretamente os direitos sociais dos indivíduos, dirigindo-se não somente ao objeto em exame, mas, como toda pesquisa, para os sujeitos.
\end{abstract}

PALAVRAS-CHAVE: Administrativo. Direito de trânsito. Advertência por escrito.

\footnotetext{
* Doutorado em Direito pela Universidade de Santa Cruz do Sul - UNISC (2014). Professora de cursos de especialização na área ambiental e constitucional na UNIVATES e UNISINOS, professora colaboradora do Programa de Pós-Graduação em Ambiente e Desenvolvimento e Professora Permanente do Programa de PósGraduação em Sistemas Ambientais Sustentáveis, ambos da UNIVATES.

** Doutorado em Direito pela Universidade de Santa Cruz do Sul, Brasil(2014). Professor Adjunto do Centro Universitário Univates, Brasil.
} 


\begin{abstract}
The present study has as scope the right of Brazilian drivers, an area that has not yet been scrutinized with the depth it deserves, notably when it comes to jurisprudence and specialized doctrine. The study is directly related to sanctions provided by the norms of the right of transit - Law 9.503/97 - and, in this context, pointedly considers the replacement of financial fines by a written warning, whose historical and social provision differs widely from the current purposes. The legal text is from the art. 267 of the Act mentioned above, known as Brazilian Traffic Code. The problem, therefore, lies in the inapplicability of written warning even in the face of the legal provision. Hypothetically there is affront to the legal sphere of the individual who suffers penalties of light or medium nature. The study has by method the qualitative research and as techniques the bibliographical and documentary analysis. The jurisprudential consultation has shown there are no results concerning this specific topic, while the doctrine imposes some requirements that are not envisioned by the legislation, which made uncontroversial, at least in this time and space, the hypothesis initially launched. The study affects directly the social rights of individuals, addressing not only the object under examination, but, like every research, the subjects.
\end{abstract}

KEYWORDS: Administrative. Rights of transit. Written warning.

\title{
1. INTRODUÇÃO
}

O trânsito, entendido como toda forma de movimentação de pessoas, é um dos maiores fenômenos da atualidade e diante das infinitas migrações verificadas diuturnamente, aliadas ao fenômeno da globalização não perderá tal status tão breve. Não é hodierno, porém, que o trânsito assim se caracteriza e daí sua relevância ao longo do tempo. Voltando na história tem conhecimento de que ainda no Império Romano haviam incontáveis estradas para deslocamento das tropas. Descreve Honorato (2004, p. 1) que referido Império "criou um sistema rodoviário com mais de 100.000 km de extensão", o que levou a fala popularmente conhecida de que todos os caminhos levam a Roma.

Sem entrar na discussão de como eram classificados os caminhos em Roma, se privados ou públicos, facilmente detecta-se que no direito de trânsito brasileiro, delineado pela lei 9.503/97, as vias possuem natureza aberta à circulação (inclusive praias e vias de 
condomínios). Para se ter ideia do alcance protetivo, os $\S \S 2^{\circ}$ e $3^{\circ}$ do art. $1^{\circ}$ do vigente Código de Trânsito estipula a obrigatoriedade das entidades do Sistema Nacional de Trânsito em assegurar para os indivíduos o direito a um trânsito seguro, sob pena de responsabilidade objetiva. Tem-se, desta forma que tal prerrogativa não contém mera indicação no sentido de se manter a segurança dos caminhos, uma vez que se coloca como corolário das garantias fundamentais da Constituição.

Veja-se o disposto nos referidos parágrafos:

Art. $1^{\circ}(\ldots)$. $\S 2^{\circ} \mathrm{O}$ trânsito, em condições seguras, é um direito de todos e dever dos órgãos e entidades componentes do Sistema Nacional de Trânsito, a estes cabendo, no âmbito das respectivas competências, adotar as medidas destinadas a assegurar esse direito.

$\S 3^{\circ}$ Os órgãos e entidades componentes do Sistema Nacional de Trânsito respondem, no âmbito das respectivas competências, objetivamente, por danos causados aos cidadãos em virtude de ação, omissão ou erro na execução e manutenção de programas, projetos e serviços que garantam o exercício do direito do trânsito seguro (BRASIL, 1997, texto digital).

Antes do atual cenário, nos remotos tempos de instituição do primeiro Código Nacional de Trânsito, o Decreto-Lei 2.994/41 (BRASIL, pré-1997, texto digital), reclamava por proteção aos caminhos que se iam surgindo com o progresso, para de certo modo pacificar e prestar segurança às pessoas que deles utilizavam. Ao proteger os caminhos, consequentemente, albergavam-se os usuários. Segundo ensina Honorato (2004, p. 3), "ao proteger-se o lugar, também se protegia por extensão as pessoas que por ele transitavam [...] ao constituir o caminho um centro de vida jurídica, surge um verdadeiro Direito do Caminho".

Para os franceses, a abrangência era maior, sendo que suas legislações sequer citavam trânsito ou tráfego, e sim, de outro modo, mencionavam "regras de circulação, acidentes de circulação, circulação internacional, etc.” (PINHEIRO, 1967, p. 13). Indiscriminadamente usadas, para este trabalho não se tem pretensões técnicas de aprofundar as expressões trânsito, tráfego ou circulação.

Como forma lógica de proteção aos utilizadores do trânsito, exsurgem as diversas formas de sanções, cujas espécies são, entre 
outras, as multas, cassação de direitos, remoção de veículos e, inclusive, os pedágios. Neste sentido Honorato (2004, p. 21-22) entende como uma forma de sanção, o que é de todo discutível.

Diante da conclusão de que uma das formas de prevenir ilícitos e conferir maior segurança aos transeuntes era, e ainda é, a aplicação de sanções aos infratores das normas de trânsito, surge no início da década de 40, o primeiro Código de Trânsito por meio do Dec-Lei 2.994, de 28 de janeiro de 1941.

Dentre as sanções previstas, possuía-se as penalidades de multa, apreensão da $\mathrm{CNH}$, retirada do veículo de circulação e admoestações. A norma geral estipulava no capítulo XII, as infrações, a contar do art. 117, cabendo destaque ao disposto no art. 118, in verbis:

As penas a que ficam sujeitos os infratores são: admoestações, multa e apreensão da carteira de condutor e retirada do veículo da circulação e recairão sobre os proprietários do veículo, sobre os seus condutores, ou sobre ambos, toda vez que incorrerem em infrações previstas conforme a classificação da tabela (BRASIL, pré-1997, texto digital).

De pouca luz, e ainda no mesmo ano adveio o Dec-Lei $3.651 / 41$ e, posteriormente a lei 5.108/66, ambos, igualmente, dotados de sanções, mas não eficientes em suas diversas funções. Após todas estas tentativas de normatização do trânsito, em 1997, publica-se o atual Código de Trânsito Brasileiro (Lei 9.503/97), estando neste último à celeuma jurídica discutida no presente trabalho; tida como escassa no âmbito judicial, mais aprofundada administrativamente, e tímida na doutrina. Este fator, entretanto, não implica no desapreço deste opúsculo, uma vez que, poderá vir a causar impactos na esfera jurídica dos indivíduos e até mesmo de determinadas coletividades.

Isto pois, judicialmente, poucos indivíduos se atrevem a ingressar com ação para discutir a comutação da sanção de multa pela advertência escrita, justamente pelo baixo valor daquela frente aos custos com a justiça, com advogado e com a possibilidade de uma hipotética sucumbência. Já no âmbito administrativo a controvérsia se coloca como favorável, pois, ao menos, posterga-se 
a confirmação dos pontos (que caducam após doze meses da data da ocorrência da infração), não existindo custas processuais.

Estas situações e gravames acabam por afastar a tutela jurisdicional destes casos jurídicos, principalmente ao desfavorecido economicamente, que não vislumbra vantagem qualquer, mesmo que a decisão lhe possa ser favorável na substituição da multa por advertência. Uma ação com tal escopo, sem embargos, possui interesse público, logo, desafiando, porque não, uma ação civil pública.

As discussões, indubitavelmente não seriam curtas e de maior simplicidade. De todo modo, pontos conflitantes não são prerrogativas apenas da lei vigente, como leciona Geraldo de F. Lemos Pinheiro, ainda na introdução do seu livro intitulado 'Código Nacional de Trânsito':

A Lei n. ${ }^{\circ}$ 5.108, de 21 de setembro de 1966, e que substituiu o antigo código de 1941, vinha sendo reclamada de longa data, e os seus efeitos, por certo, só serão sentidos após algum tempo de aplicação e educação. Antes que tal aconteça, as interpretações devem ser feitas com cautela, mesmo porque muito ponto controvertido, e até contraproducente, foi colocado no estatuto (PINHEIRO, 1967, p. introdução).

Não apenas reclamam-se novas legislações, mas, igualmente, adaptações e explicações provenientes da doutrina e dos tribunais judiciários, em busca de justa aplicabilidade das regras, levando-se em consideração a razoabilidade e proporcionalidade, principalmente na aplicação das sanções aos administrados. Daí decorre a preocupação do autor retro, no que respeita às interpretações serem praticadas com cautela (causa imanente também deste artigo).

A lei 5.108/60 também previu em seu art. 95, combinado com o art. 108, a hipótese de substituição da multa pela advertência, que na época, não era detalhada como escrita ou por outro meio. Leiamse tais regras, para esclarecimento:

Art. 95. O responsável pela infração fica sujeito às seguintes penalidades: a) advertência; b) multa; c) apreensão do documento de habilitação; d) cassação do documento de habilitação; e) remoção do veículo; f) retenção do veículo; g) apreensão do veículo. 
Art. 108. A autoridade de trânsito poderá transformar a primeira multa decorrente de infrações dos Grupos " 3 " e "4", em advertência, levando em conta os antecedentes do condutor (BRASIL, pré-1997).

Destarte, há motivos que revelam a natureza escrita, já que o art. 107 ordenava como consectário indireto, a anotação da multa anterior, com escopo de possível aplicação em dobro da pena na reincidência (anotada anteriormente). Recomendava-se, assim, conforme Pinheiro (1967, p. 317) que a advertência fica-se consignada no prontuário do motorista, sendo, portanto, escrita.

Superada, entretanto, a fase da lei dos anos 60, entrou em vigor no ano de 1997, a alhures aludida lei federal nominada como Código de Trânsito Brasileiro. A contar do art. 161 (genericamente), a lei 9.503/97 elenca uma gama de situações fáticas (e algumas jurídicas) que são consideradas infrações sujeitas à sanção. Estas, por sua vez, são gradativamente qualificadas (desde leves, passando por médias, graves, até as gravíssimas) nos moldes do art. 258 da lei retro mencionada e agora transcrita: "Art. 258. As infrações punidas com multa classificam-se, de acordo com sua gravidade, em quatro categorias: (...)".

Sobrepujadas a tal qualificação, encontram-se às espécies de penalidade, quais sejam: advertência por escrito (objeto do artigo), multa, suspensão do direito de dirigir, apreensão do veículo, cassação da habilitação ou da permissão, frequência em reciclagem. Entretanto, é unicamente sobre a medida sancionatória de advertência por escrito que versarão as razões a partir deste momento.

$\mathrm{O}$ interesse desta matéria atinge diretamente a esfera jurídica dos indivíduos, ao mesmo passo que se observa que a legislação de trânsito tem muito ainda a avançar quanto à sua aplicação e estudo, para que se torne realmente uma normatização com desideratos de prevenção e educação no trânsito - primariamente - passando a atuar repressivamente, somente num segundo plano; de forma diversa do que tem ocorrido na atualidade. Assim, no capítulo próximo apresentar-se-ão os planos essenciais da conduta administrativa no que respeita à aplicação de sanções ao administrado. 


\section{INFRAÇÕES DO CTB E SUAS GENERALIDADES}

A aplicação de qualquer sanção no âmbito administrativo pressupõe, numa primeira investida, a observância do princípio da legalidade. Nada mais sagrado que o respeito ao elemento fundamental que rege a administração pública, previsto, ainda no art. 37 da Carta da República Federativa, onde ordena que aquela, sempre reger-se-á pela lei. Em virtude disto, inclusive no direito de trânsito, quando da autuação do suposto infrator, o agente de trânsito tem a obrigação de respeitar os ditames legais.

Apresentadas estas preliminares, pode-se referir que "o princípio da legalidade [...] significa estar a Administração Pública, em toda a sua atividade, presa aos mandamentos da lei, deles não se podendo afastar, sob pena de invalidade do ato" (GASPARINI, 1989, p. 6).

Indiferentemente, avulta-se conteúdo idêntico quando se instaura o processo administrativo, abrindo prazo para defesa e recursos, bem como, da instrução probatória quando permitida - o que dificilmente se verifica no processo administrativo de trânsito devendo ser levados sempre em consideração os preceitos legais. Por lógica, não menos importantes são os demais, como o devido processo legal, a ampla defesa, o contraditório e o tempo razoável do processo, mas, estes, também possuem suas regras estritamente legalizadas, portanto, não se furtando ao correlato princípio.

Ocorre, no entanto, que apreciando os tipos de infração previstas no Código de Trânsito, vislumbra-se que, sequer uma delas, estabelece a advertência por escrito como sanção incipiente e aqui jaz a perquirição do trabalho, sobre a inclusão na lei de trânsito de dita possibilidade. Ora, se o princípio da legalidade permite esta possibilidade, mesmo que sendo uma faculdade ao Poder Público, ao menos num ou outro caso haveria a aplicação da regra, fato que o autor até hoje não verificou (nem mesmo em jurisprudência).

Deve-se sempre ter mentalizado que, dentro do sistema punitivo do direito de trânsito, nos moldes adiantados acima, as sanções são tratadas pela sua gravidade e conforme o tipo administrativo infringido, sendo maiores ou menores as repercussões coercitivas ao indivíduo. É nada mais que, uma forma de lidar diferente com dadas situações que também não se mostram iguais por força da lei, que leva em consideração a potencialidade e 
efetividade da ofensa à sociedade.

A possível aplicação da pena de advertência escrita é condicionada pelo art. 267 do CTB, prevendo razões objetivas e uma subjetiva para a concessão (improvável e desconhecida da praxe) da substituição. Para prosseguir o estudo, deve-se ter intimamente caracterizada a premissa de que sanções são necessárias para manutenção do Estado e sua ordem social, contudo, a regência das mesmas deve se coadunar com a lei e, ademais, observar critérios proporcionais e razoáveis. Neste ponto expõe-se que sanção é característica de "uma conseqüência da conduta considerada nociva à sociedade" (KELSEN, 1998, p. 73, sic), e, logo, estas condutas nocivas, devem ser punidas. Disso, aliás, não se infere dúvida, uma vez que uma lei sem poder de coerção, talvez possa nem ser reconhecida como tal.

Assim, não se pretende em nenhum momento asseverar que em todas as situações deverá ser aplicada a substituição da multa, no entanto, a oportunidade de sua eficácia em determinadas ocasiões não pode ser desperdiçada pelo alvedrio dos agentes públicos que julgam as defesas e recursos administrativos de trânsito - seguindo ou não orientação hierárquica no sentido da negativa. Cumpridos os requisitos, a utilização da substituição da multa pela admoestação escrita deve suceder. Quais são, então, os referidos pressupostos de aplicabilidade da advertência por escrito? É o que se verá à frente.

\section{OS REQUISITOS PARA A ADVERTENCIA POR ESCRITO: BREVE CONTEXTO DAS RESOLUÇÕES DO CONTRAN}

Apresentadas as linhas gerais para fins meramente de introdução ao eixo central do artigo, cabe certificar, com dura crítica em verdade, que até a atualidade, ainda não houve a regulamentação pelo Poder Executivo do art. 267 do CTB, para que pudesse o mesmo, bem ou mal, ser aplicado.

Com os reclames e a propagação de e-mails pela rede mundial de computadores (internet), a população tomou conhecimento desse direito e iniciou uma demanda pela sua utilização (todavia, pouca adesão parece ter tido, mas, com alguns frutos). Em 2011 foi publicada a Res. 363 do Contran, de 28 de outubro de 2010, que 
teoricamente, viria a regular a substituição das infrações pela advertência por escrito, nos termos do art. 267 (DENATRAN, 2011, texto digital).

Entraria em vigor após decorridos 360 dias da publicação oficial, portanto, somente em outubro de 2011. Em seu art. 10, a Resolução trabalhou a prospecção de atuação frente aos pleitos de substituição da multa, porém, nada clareando a mais do que se poderia absorver da simples leitura do disposto na lei ordinária $\mathrm{n}^{\circ}$ 9.503/97:

Art. 10. Em se tratando de infrações de natureza leve ou média, a autoridade de trânsito, nos termos do art. 267 do CTB poderá, de oficio ou por solicitação do interessado, aplicar a Penalidade de Advertência por Escrito, na qual deverão constar os dados mínimos definidos no art. 280 do CTB e em regulamentação específica (DENATRAN, texto digital).

Não durou muito a eficácia da tal resolução. No ano seguinte de sua vacância, o Contran publicou a Res. 404, na data de 12 de junho de 2012, com preâmbulo repetindo sua precedente:

Dispõe sobre padronização dos procedimentos administrativos na lavratura de auto de infração, na expedição de notificação de autuação e de notificação de penalidade de multa e de advertência, por infração de responsabilidade de proprietário e de condutor de veículo e da identificação de condutor infrator, e dá outras providências (DENATRAN, 2011, texto digital).

Para se ter noção do caótico aparato resolutivo do Contran, a novel Res. 404, publicada inicialmente em 12 de junho de 2012 e republicada em 25 de junho do mesmo ano, entraria - como entrou em vigência no dia $1^{\circ}$ de janeiro de 2013 , entretanto, revogou de imediato (na data de sua publicação e não de vigência) a Resolução 363, que foi sua precedente. Repristinou a antiga - inútil e antiquada - Res. 149/03 que nada de concreto possuía - era pior que a Res. 363 - uma vez que só teria eficácia em janeiro de 2013.

O exame criterioso destas normas jurídicas denúncia o quanto confuso se colocava o panorama normativo acerca da matéria. Vejam-se dois exemplos contidos na Res. 404/12. Dispôs o artigo 28: "Fica revogada, a partir da publicação da presente Resolução, a 
Resolução n ${ }^{\circ}$ 363/2010 do CONTRAN". Sua publicação ocorreu em junho de 2012. No segundo exemplo, verifica-se: “Art. 27. Esta Resolução entrará em vigor no dia $1^{\circ}$ de janeiro de 2013, quando ficará revogada a Resolução $n^{\circ}$ 149/2003 do CONTRAN". Um cipoal absurdo de resoluções, que apenas dificultam a aplicação e o entendimento das mesmas.

No vértice substancial da penalidade de advertência por escrito, a disciplina foi esmiuçada no art. $9^{\circ}$ da Res. 404/12. Igualmente tratou apenas de trâmites do processo e da forma de comprovação (ou não) da reincidência com atualização dos cadastros dos prontuários dos condutores e proprietários (esqueceu-se, como se denota, dos pedestres, que também podem ser infratores, tanto como dos que não são condutores - vide Res. 390/11 do Contran que nada prescreve quanto à substituição para estes dois agentes).

Tampouco a detecção exata da problemática e nem mesmo sua resolução virão pelo novo ato executivo exarado [a Res. 404/12], eis que, lhe faltam detalhes importantes sobre a substituição da multa e das próprias concepções dos termos da advertência. Restará a condução técnica do assunto à jurisprudência e a doutrina, o que se procura conduzir neste instante, a partir de algumas ideias.

\subsection{Pressupostos propriamente ditos}

Não se pode deixar de reconhecer a problemática do descumprimento das normas de trânsito, haja vista que, por mais estreme que aparente ser, poderá a infração ser causa de acidente a qualquer instante. Em que pese às críticas traçadas anteriormente, a construção e aperfeiçoamento legal devem ser tidos como incessante objetivo no direito de trânsito, em especial com educação e sanção adequada. Ainda nos anos 60, bradava Geraldo de F. L. Pinheiro:

Não se pode desconhecer a importância que os problemas de trânsito e direção de veículos automotores vêm tomando nestes últimos tempos, quer pelo crescente aumento das máquinas e seu uso para tôdas atividades humanas, quer pelo constante aperfeiçoamento procurado pelos fabricantes - em verdadeira competição - a fim de dar maior potência aos motores.

As leis de contrôle do trânsito devem acompanhar as invenções e aperfeiçoamentos dos fabricantes e a administração pública deve 
estar aparelhada para enfrentar a costumeira legião de infratores, descuidados ou ineptos (PINHEIRO, 1967, p. 186).

Fora de qualquer dúvida há de se questionar estas premissas, pois, se o legislador acomodar as regras jurídicas num determinado ponto cronológico, as infrações previstas, com o passar do tempo, se tornarão inócuas. No início das discussões aqui travadas tratou-se da importância da cominação de infrações para o direito administrativo, sob o risco de deixá-lo sem razão (Kelsen, 1998). Contudo, a razão também é mantida com a atualização compassada das sanções diante das realidades sociais. De igual sorte, se apresenta a (má) versão aposta no art. 267 do CTB, estando inexistente de motivação no contexto atual da codificação de trânsito e social.

De qualquer jeito, trazê-lo à cena neste momento é de salutar iniciativa, para que os leitores se coloquem a par das extremidades legais do que se mostra como 'eixo central' do opúsculo: a proposição jurídica do art. 267 do código de trânsito. In litteris:

Art. 267. Poderá ser imposta a penalidade de advertência por escrito à infração de natureza leve ou média, passível de ser punida com multa, não sendo reincidente o infrator, na mesma infração, nos últimos doze meses, quando a autoridade, considerando o prontuário do infrator, entender esta providência como mais educativa (BRASIL, 1997, texto digital).

Tem-se, pois, a regra jurídica que carece de aplicação no mundo fático. Como se depreende, alguns requisitos são de sumária cognição, não criando maiores percalços em sua aplicabilidade. Arnaldo Rizzardo em sua doutrina destaca quatro pressupostos básicos:

Como condições para operar a liberalidade, enumeram-se os seguintes requisitos:
a) a prática de infração de natureza leve ou média;
b) a previsão da penalidade de multa;
c) não ser o infrator reincidente na mesma espécie, nos últimos doze meses;
d) o entendimento, em vista do prontuário do infrator, de que a advertência será mais educativa que a multa (RIZZARDO, 2003, p. 562). 
Nos termos integrais da regra e do trecho doutrinário, exclusivamente as multas leves e médias podem ser substituídas, quando esta natureza estiver assim ministrada na legislação, preenchendo-se, por óbvio, o primeiro requisito. Não há muito que se discorrer neste ponto. Depende a completude da exigência, simplesmente que a lei de trânsito estipule a gravidade da infração como sendo de natureza leve ou média. Prevendo-se outra, inexiste a faculdade do uso da substituição.

Destarte, estas delimitações das qualidades de cada espécie de infração estejam reservadas a uma dada legislação, nada mais são que vontades dos jurígenos, que no caso, por força da Democracia Representativa que se funda o Estado brasileiro, é tida por representação da vontade geral do povo. A plebe, portanto, é que alcança subsídios, através de sua vontade geral, para que os representantes legislativos selecionem a gradação que terá cada tipo de infração - não diferente sucede na lei 9.503/97.

Dogmatismo este, que, segundo Marinoni, já não é mais encontrado nas legislações presentes, sendo que, a lei que antes expressava a vontade geral, advinda de um Parlamento burguês e sem confrontos ideológicos não mais existe (2000). Explica, ademais, que, passada esta fase, o "Parlamento não é mais o lugar da uniformidade ideológica" e, obviamente, a toda "evidência, não há mais uma vontade geral, podendo-se falar em uma 'vontade política', a vontade do grupo mais forte dentro do Parlamento" (MARINONI, 2000, p. 186).

Estes eram os panoramas impregnados na construção das legislações, dentre elas, a própria codificação de trânsito. O Parlamento, no âmago de suas atribuições e deliberações, escolheu a forma que teve por apropriada para a graduação das sanções de trânsito. Infelizmente, não se conhece a exata dimensão do que fora estatuído no CTB e de seu porque, haja vista que, consoante Marinoni (2000, p. 186), "a lei contemporânea, na realidade, é muito mais fruto do lobby e das pressões de grupos do que a expressão de uma ideologia", por mais divergente que ela - a ideologia - seja.

Portanto, este o primeiro dos critérios objetivos e diretos para a admissibilidade da ocorrência da substituição da multa que seria aplicada, por uma advertência por escrito: a graduação da infração como natureza leve ou média. 


\subsection{Previsão de multa para o tipo: mero formalismo legislativo}

Novamente, uma das características de condição elementar, encontra-se diante de várias críticas. Sugerem ser questiúnculas, mas, que não passam despercebidas. Sucede que este critério - de previsão de multa para a infração - para ocorrência da substituição é desastrosa inclusão parlamentar no texto da regra jurídica, posto que, todas as infrações aplicáveis no CTB preveem tal sanção pecuniária, seja primária ou secundária e, sempre cumulativa quando não for primária. Desde a mais gravíssima das infrações, obedece-se esta tônica, por vontade legal, de imputar, conjunta ou isoladamente, punição em cifras monetárias.

Deixa-se de sinalizá-lo, então, como exigência, numa técnica de compreensão lógica do código de trânsito, já que, é comum a todas as infrações a aplicação da multa, portanto, não cabendo diferenciações no atinente à aplicação da substituição em comento. Se no art. 267 do CTB houve expressa previsão de que a comutação exigiria a previsão de multa pecuniária ao infrator - naquela que seria a sanção original - foi apenas para não tornar tecnicamente inútil o preceito legal, ante a aplicação de multa para todas as infrações do CTB.

Acaso de outra maneira previsse o artigo retro, sem disciplinar a substituição para as infrações 'passíveis de serem punidas com multa', só ocorreria a troca de 'penas' se não fosse prevista a punição com multa. Neste caso, o artigo estaria, incontroversamente mais inutilizado do que hoje se encontra na prática, pois, como declarado, todas as infrações possuem a multa como pena.

Ademais, numa segunda interpretação, se nada constasse na norma jurídica descrevendo a substituição a ser utilizada nas infrações punidas com multa, ela poderia se estender a todos os tipos de infração, o que também não agradaria.

\subsection{Não reincidência específica nos últimos 12 meses: crítica à doutrina}

A exigência prevista neste tópico é a causa de intrigas secundárias, que se qualificam como questão de direito, no que tange à sua averiguação, qual seja, a 'não reincidência específica do infrator nos últimos 12 meses'. Quando em interpretação 
intrassistêmica, no bojo do próprio art. 267, entrelaçada com a "dignidade do prontuário do infrator" que permita uma sanção mais educativa, tem-se altas doses de controvérsia jurídica. Mas isto se elucidará no subcapítulo abaixo.

$\mathrm{Na}$ aplicação deste item, mesclam-se os antecedentes com o critério temporal dos mesmos. Em síntese, não havendo reincidência na mesma infração, dentro dos doze meses precedentes à infração que se pretende substituir, satisfeito estará o juízo. É critério objetivo e direto, se pensado quanto às infrações e ao tempo, mas subjetivo quanto à pessoa, já que diz respeito ao infrator.

Apesar disso, o caráter para fins instantâneos, igualmente, é objetivo e, portanto, de fácil aferição quando do recebimento da notificação de autuação da infração. Não circundam gravames de cognição nos institutos até o momento ilustrados. Tanto a administração pública, quanto o próprio infrator possuem plena facilidade para produção da prova do fato negativo, qual seja, a não sujeição à infração de mesma espécie nos últimos doze meses, situação que autorizará a satisfação de mais um dos requisitos legais para a substituição. Importante deixar claro que não se imputa, nem se discute ônus probatório neste momento, tão somente, de forma exemplificativa, referenda-se que qualquer das partes tem condições de produzir a prova.

Apenas para firmar o entendimento, os doze meses retroagem da multa que se pretende a substituição, ou seja, no respectivo período, não pode o infrator ter sofrido outra multa de mesmo enquadramento, verificando-se para isso, até mesmo, incisos ou alíneas que possam conter o artigo infringido $-v . g$ o art. 162, que contém vários incisos, o art. 176, com idêntico formato, e ainda, o art. 231, com incisos e alíneas, todos da 9.503/97.

Verificados os componentes legais, segundo arrazoados antes ilustrados (pelo simples método exegético, ou pela sistematização dos preceitos referentes à infração), revela-se inevitável o conhecimento da parte final do art. 267 do Estatuto do Trânsito, na condicionante a ser decidida pelo julgador administrativo, quanto ao 'prontuário apto a tornar a providência da substituição da multa por advertência escrita mais educativa'. Lembrando-se que exclusivamente se chegará a este nível de exame, quando transpassados todos os demais requisitos já abordados, de cunho objetivo. 


\section{CONSIDERAÇÃO DO PRONTUÁRIO DO INFRATOR PARA O ESCOPO DA MEDIDA MAIS EDUCATIVA}

Este item - exigência do art. 267, assim como as antes vistas possui tamanha importância e destaque que merece discussão apartada das demais questões. A inobservância das lógicas interpretativas jurídicas causa desprezível prejuízo aos indivíduos quando postulam o benefício do artigo retro, que é visto pela administração, para fins de negativa, como simples falta de regulamentação (que desde 1997 ainda não veio suficientemente, como já se elucidou anteriormente).

Apresentou-se alhures, as resoluções do Contran, e como se pode notar, nenhuma delas esclareceu ou explicou quais seriam os prontuários aptos a receber a substituição da multa. Porém, isto tem acontecido por pura incompetência do órgão executivo responsável, pois houve unicamente a deliberação quanto ao processo administrativo para fins de postular o direito (v.g. previsão de recurso, criação de órgão integrado de prontuários).

Em nenhum momento, a regulamentação do Poder Executivo ingressou no mérito das situações descritas no artigo de lei referendado, ou pelo menos não naquelas tidas como exigências para por em prática o direito do cidadão ali previsto. É o que se buscará fazer doravante, tentando estancar a lacuna deixada, ao menos incipientemente - e talvez não com a devida intelecção que merecesse a matéria. Todavia a teoria deve ser iniciada, para que, futuramente, seja criticada e melhorada. As teorias são temporais, devendo constantemente sofrer modificação (MARINONI, 2000, introdução).

Nestas linhas, então, qual seria o prontuário digno de ser 'premiado' com a substituição da multa pela advertência escrita? Deveria o legislador ter fixado na lei de trânsito, parâmetros para o julgamento administrativo do prontuário apto para tal concessão coisa que o Poder Público também não fez nas regras executivas. Ao contrário, preteriu qualquer distinção ou determinação para tal desiderato, até por não ser de seu interesse substituir a multa, que gera receitas ao Estado lato sensu, por uma carta de advertência ao infrator, que só gera despesas.

Consigna-se que o art. 256 do CTB declara como primeira sanção aplicável, justamente a advertência escrita, mas, que, por 
inoportuno, não é aplicada em nenhuma infração e em nenhum caso. É letra jacente na lei de trânsito (falecendo no campo da aplicabilidade). Entretanto, reportando a questão antes mencionada (sobre o prontuário passível de comutação da multa), qual então seria (ou é) a solução jurídica para tanto? Distanciando-se de tal pretensão (sem deixar de enfrentar o tema), adentra-se na apresentação, de como melhor se adéqua a parte final do art. 267 do CTB ao sistema Constitucional vigente.

Rápida digressão é necessária para recordar a natureza da previsão da substituição da multa. Consoante certificado pela doutrina, "a finalidade máxima das penalidades por infrações é também a reeducação, não sendo, pois, o intuito do Código puramente de reprimir e punir, se abrem possibilidades de substituição da pena de multa pela de advertência” (RIZZARDO, 2003, p. 562). No entanto, as possibilidades são afuniladas e esbarram em procedimentos administrativos que visam, pura e simplesmente, a arrecadação e a punição do infrator.

Destaca-se a orientação próxima, de certa forma simples, mas que deve ser levada em consideração, pois, quis o legislador, quanto ao prontuário, não exigir um prontuário sem antecedentes (primário), mas, por outra margem, um que habitualmente não se envolva em infrações. Valorizando, então, como nomeia o autor Moreira Alves, aspecto "de relevante importância social" (MOREIRA ALVES, 2000, p. 223).

Na parte inicial do debatido artigo o legislador escolheu punir a reincidência específica dentro de determinado lapso temporal isto, diga-se de passagem, é clarividente, porém, merece reforço - e, ao assim determinar, acabou por afastar a possibilidade de apenas comutar sanções quando o réu fosse primário. Explica-se: caso quisesse enxotar toda e qualquer reincidência no caso do art. 267 do CTB (que, por conseguinte, seria a exclusão de antecedentes), não detalharia o afastamento tão somente da reincidência específica e, ainda, com limite temporal.

Aclama-se em realidade, a presunção de inocência do art. $5^{\circ}$, inc. LVII da CF/88. Se o prontuário crível de substituição fosse calcado na primariedade, inócua seria a prescrição da "não reincidência específica', justamente, porque se esta se verificasse no plano fático, impediria a primariedade, bem como, se não se 
vislumbrasse, igualmente poderia redundar em falta de primariedade (pela reincidência genérica).

Bastaria, portanto, ao legislador, se quisesse privilegiar apenas o prontuário primário pelo art. 267 , descrever em tal sentido (ou quedar-se silente), e não efetuar menção a prontuário - que releva e revela um histórico - com vedação a reincidência especial nos últimos doze meses, ou seja, permitindo as demais.

Se o preceito legal for interpretado no sentido de que a primariedade é necessária, de nada interfere a classificação da reincidência específica realizada, tornando, por consequência, os infratores todos comuns (quanto à reincidência geral e especial), ao contrário do que diferenciou o legislador. Por imposição da norma, somente é defeso a reincidência específica nos últimos 12 meses, portanto, e por lógica interpretativa, não está afastada a reincidência genérica, assim como não está a específica anterior aos últimos 12 meses (ou seja, elas são permitidas para o caso da substituição). Por isso, se pode certificar que inexiste a predisposição da primariedade do prontuário para que o mesmo esteja apto a receber a substituição.

Em sentido reverso, concessa vênia, faz-se importante apresentar outras posições, - e aqui reside a principal crítica:

A penalidade de advertência por escrito (art. 256, I, combinado com o art. 267) tende a ser letra morta, tal como já ocorria ao tempo do Código Nacional de Trânsito (art. 95, letra a), pois não existe integração de todos os órgãos afim de que aquele que detém o prontuário do condutor faça o devido registro para informação plena da primariedade do condutor. A única possibilidade de aplicação da pena substitutiva seria transferir ao infrator a prova de sua primariedade, o que se revela praticamente impossível (PINHEIRO; RIBEIRO, 2000, p. 420).

Não diretamente, e por duas vezes, é afirmado que a primariedade deve estar presente para a possível conversão das sanções. Arnaldo Rizzardo (2001) segue nesta esteira, imputando que se nenhum registro houver contra o condutor ou proprietário, deve-se consolidar o direito. Declara o autor, que satisfeitos os demais elementos, há obrigatoriedade em proceder-se à substituição apenas no caso de não haver registro no prontuário do condutor (RIZZARDO, 2003, p. 562). Veja que o autor não possibilita outras 
dilações. De modo divergente, apega-se o presente estudo. Há outros critérios para determinar a autorização da substituição neste aspecto do prontuário.

Nesta perspectiva, o bom prontuário não é (nem poderia ser), de sobremaneira, o primário, como referências postadas; por outro viés, poderia ser digno de conversão, um prontuário sem excesso de multas, sem a reincidência específica do art. 267, sem multas gravíssimas, e, por que não dissertar, não ser o infrator, incurso em crime de trânsito nos últimos 05 anos (antecedentes criminais).

Consoante o Parecer 143 do Cetran/SC, em consulta formulada e julgada em outubro de 2011, seu relatório sugere algumas premissas da análise do prontuário nos termos do art. 267 do CTB:

Assim, para investigar o atendimento do fim educativo da medida, basta que, da análise dos registros existentes na repartição, se verifique que essa pessoa não é relapsa no cumprimento de suas obrigações e que uma advertência seria o suficiente para fazer com que sinta o peso da responsabilidade pelo ilícito praticado (CETRAN/SC, texto digital).

Permite-se, em vista disso, incluir entre os prontuários com aptidão para a substituição, os que possuam reincidência específica mais antiga do que os 12 meses prévios ao dia da multa a ser substituída, e indiferente, quanto à reincidência genérica, com observância dos critérios alvitrados acima (o que, incontroversamente, afasta a primariedade). A ideia de primariedade de prontuário falece diante das perspectivas elaboradas.

Os critérios propostos no texto partem de uma interpretação metódica e contemplam uma proposta de aperfeiçoamento. A nota anterior (CETRAN/SC) confere suporte essencial para tal pensamento, pois, suplanta o conceito de subjetividade do julgador na esfera executiva, sem que este esteja vinculado ao prontuário primário do infrator. Observando que a subjetividade, apesar de não muito propícia à segurança jurídica, deve ser aqui pensada como forma de moralidade e não para fins de criar abusos contra os administrados. Esta, talvez, o maior entrave para uma administração pública eminentemente arrecadadora. 
Respeitando as doutrinas referenciadas acima, de reconhecidos jurisconsultos do direito de trânsito, modestamente se traz à cena uma proposta nova quanto à aplicação da regra legal em comento. Sem a pretensão de se apresentar a melhor solução para o problema posto, tem-se que uma das missões do jurista diz respeito ao apontamento das ilegalidades contumazes, que devem um dia, num plano utópico de justiça social, ser banidas da esfera do direito de trânsito.

\section{CONCLUSÃO}

Denota-se ao cabo desta discussão, que o legislador quis efetivamente atenuar, pelo art. 267 do CTB, as penas aos participantes do trânsito que por algum deslize se tornem infratores (gradação leve ou média). Todavia, como não cominou diretamente a pena de advertência em tais casos, concedeu a oportunidade de em defesa, o suposto infrator (preenchidos os requisitos legais) alegar e requerer a comutação prevista no plano normativo. Apesar da falta de elucidação do texto legal, através de acurada sistematização intelectiva, se pode prevenir a utilização das premissas aportadas neste artigo, pois, representam a vontade geral e a verdadeira intenção legislativa de (re)educação no trânsito.

É fora de questão cogitar a inaplicabilidade da substituição da multa por advertência escrita pela não análise do prontuário que não esteja qualificado como primário, ainda, devendo ser observados os critérios retratados no desenvolvimento e, não simplesmente, o interesse em receitas da entidade e o abuso de direito dos agentes públicos que examinam os pedidos administrativos, de tal sorte que, a primariedade não pode ser parâmetro para afirmar qual o prontuário apto à substituição, pois a lei não fez tal exigência.

Antes de qualquer ato, devem ser examinados critérios objetivos da substituição. Estes critérios são resumidamente: a) infração leve ou média; b) passível de punição com multa; c) não reincidência específica; d) pelo período de 12 meses. Enquadradas estas, chega-se à análise do prontuário.

Logo, predispostas e ultrapassadas as condicionantes tidas como objetivas, quando da avaliação do prontuário, para verificação de sua aptidão ao recebimento de medida educativa (advertência por 
escrito) ao invés da multa, a administração pública deve (obrigação) levar em consideração que não é imprescindível a primariedade do prontuário do infrator - e isto, inclusive, se mostra incontroverso para que seja deferida a substituição das penas. Por outra borda, deve atender os sugestivos acima vistos, para que não mantenha o estatuto do art. 267 da Lei 9.503/97, na condição de inútil e falecida regra jurídica.

Os demais critérios subjetivos deveriam estar padronizados em regulamento - ou lei - para que pudessem conferir certa segurança ao julgamento. Como não estão, sugere-se a utilização de critérios éticos e morais, como os dispostos no item 4 deste artigo, dentre os quais: não possuir excessivas multas; o cumprimento com outras obrigações de trânsito; não reincidência específica; não cometimento de multas gravíssimas, e não envolvimento em crimes de trânsito. Estas, apenas sugestões, que podem ser levadas em consideração no momento do exame do prontuário do condutor para fins de substituição da multa por advertência na forma escrita.

Pode-se determinar, tão somente como informativo, que o referido artigo de lei possui enorme e inconfundível predisposição de atuação em prol dos cidadãos, todavia, por sua falta de organização e regulação, que até hoje não existe eficazmente, por mera involuntariedade da administração pública, não vem sendo aplicado, ferindo os interesses da população, que a princípio, até onde se compreende por Estado Democrático, representa a coletividade e a vontade geral da lei.

\section{REFERÊNCIAS BIBLIOGRÁFICAS}

BRASIL. lei 9.503/97. Todos os artigos desta legislação foram retirados do site do Planalto, repositório oficial da legislação no âmbito federal disponível e atualizada no site <http://www.planalto.gov.br/ccivil_03/leis/L9503.htm>. Acesso em: 2011-12. . Legislação federal de trânsito precedente à lei 9.503/97 (pré). Sítio de pesquisa <www.lexml.gov.br>. Acessos em 2012.

DENATRAN. Atos executivos do Contran. Retirados do site oficial do Denatran. Disponível e atualizado no site <www.denatran.gov.br/resolucoes.htm>. Acesso em: out/dez 2012. 
CETRAN/SC. Parecer 143 do Conselho Estadual de Trânsito de Santa Catarina. Retirado do site: <http://www.cetran.sc.gov.br/pareceres/parecer143.htm>. Acesso em: 06/12/2011.

GASPARINI, Diógenes. Direito Administrativo. São Paulo: Saraiva, 1989.

HONORATO, Cássio Mattos. Sanções do Código de Trânsito Brasileiro: Análise das penalidades e das medidas administrativas cominadas na Lei 9.503/97. Campinas, SP: Millennium Editora, 2004.

KELSEN, Hans. Teoria Geral do Direito e do Estado. Tradução de Luiz Carlos Borges. 3. ed. São Paulo: Martins Fontes, 1998.

MARINONI, Luiz Guilherme. Novas linhas do processo civil. 4. ed. rev. e atual. São Paulo: Malheiros Editores, 2000.

MOREIRA ALVES, José Carlos. Direito Romano, v. II, Instituições de direito romano; b) parte especial: direito das obrigações, direito de família, direito das sucessões. 6. ed. Rio de janeiro: Forense, 2000.

PINHEIRO, Geraldo de Faria Lemos; RIBEIRO, Dorival. Código de Trânsito Brasileiro Interpretado. São Paulo: Ed. Juarez de Oliveira, 2000.

PINHEIRO, Geraldo de Faria Lemos. Código Nacional de Trânsito (comentado): veículos e culpa. São Paulo: Saraiva, 1967.

RIZZARDO, Arnaldo. Comentários ao código de trânsito brasileiro. 3. ed., rev., atual. e ampl., São Paulo: Ed. Revista dos Tribunais, 2001.

. Comentários ao Código de Trânsito Brasileiro. 4. ed., São Paulo:

Editora Revista dos Tribunais, 2003. 
